\title{
Energy and exergy analysis of dry-steam geothermal power plant: Case study in kamojang geothermal power plant unit 2
}

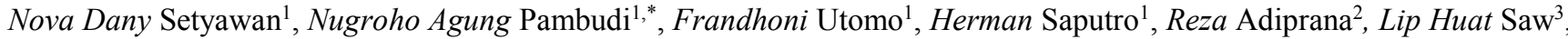 \\ Mert Gürtürk ${ }^{4}$, and Bayu Rudiyanto ${ }^{5}$ \\ ${ }^{1}$ Universitas Sebelas Maret, Mechanical Engineering Education, Jl. Ir. Sutami 36A, Surakarta 57126, Indonesia \\ ${ }^{2}$ PT. Indonesia Power, Kamojang Geothermal Power Plant \\ ${ }^{3}$ UTAR, Lee Kong Chian, Faculty of Engineering and Science, Selangor, 43000, Malaysia \\ ${ }^{4}$ Firat University, Technology Faculty, Department of Energy Systems Engineering, 23100 Elazig, Turkey \\ ${ }^{5}$ Politeknik Negeri Jember, Energy Engineering Laboratory, Department of Renewable Engineering, Jember 68121, Indonesia
}

\begin{abstract}
The Government of Indonesia is committed to realize a policy of 35,000 Megawatt (MW) of an additional supply of electricity within 5 years (2014-2019). The projection of this capacity is largely supported by fossil fuel power plants and a small portion of renewable energy. One of the renewable energy which currently has great potential in Indonesia is the geothermal. Therefore, improving the capacity of geothermal is needed to support the policy. The Kamojang is one of the largest geothermal power plant in Indonesia with an installed capacity of $235 \mathrm{MW}$ from 5 generating units. The purposes of this research is to calculate the energy and exergy analysis at Kamojang geothermal power plant. To improve the capacity, exergy analysis can be used by employing the thermodynamic method. In this research, unit 2 of Kamojang's plant is employed. The analysis was examined by using the Engineering Equation Solver (EES) code. The results show the first law of efficiency was calculated at $19.03 \%$ and the second law of efficiency at $40.31 \%$
\end{abstract}

\section{Introduction}

The Government of Indonesia is committed to realize the supply of electricity amounting to 35,000 Megawatts (MW) within 5 years (2014-2019). This projection is largely covered by the fossil fuel power plants, such as coal and gas. In supporting this policy, power plants from new and renewable fuels such as wind, hydro, geothermal and sunlight also plays an important role for energy security. Geothermal is one of the energy that has a huge potential in Indonesia. This potential is scattered along volcanic belt paths starting from Sumatra, Java, Bali, Nusa Tenggara, North Sulawesi, and Maluku. Referring to the geothermal investigation conducted by Geological Agency, it has been identified as many as 312 geothermal potential points until 2013 [1]. The total geothermal potential available is $28,910 \mathrm{MW}$ with a total reserve of about 16,524 MW. However, the installed capacity of geothermal power plants until 2014 reaches only $1,403.5 \mathrm{MW}$ or $4.9 \%$ from the available potential. Indonesia's geothermal potential is the 2 nd largest in the world $(13 \%$ of world potential), but the installed capacity is only number 3 in the world. In the government projection, geothermal power plants are planned to have an installed capacity of $3,195 \mathrm{MW}$ by 2019 [2]. To support the expansion and upgrading of $35,000 \mathrm{MW}$ capacity, geothermal energy can be one of the optimized energy sources.
Currently there are several geothermal power plants such as Kamojang (235 MW), Lahendong geothermal power plant $(80 \mathrm{MW})$, Sibayak geothermal power plant (12 MW), Salak geothermal power plant (377 MW), Drajat geothermal power plant $(270 \mathrm{MW})$, Wayang Windu geothermal power plant (277 MW), Dieng geothermal power plant (227 MW), Ulubelu geothermal power plant (110 MW), Ulumbu geothermal power plant (10 MW), Mataloko geothermal power plant (2.5 MW) and geothermal power plant Patuha (55 MW) [3]. More details towards the plant in Kamojang, currently has five power plants, units 1, 2 and 3 owned by Indonesia Power and units 4 and 5 operated by Pertamina Geothermal Energy. The production wells that have been developed since 1976 had supplied 1,500 tons / hour of steam for units 1, 2 and 3. These wells suffers a decrease in steam production by about $3 \%$ per annum due to a drop in reservoir pressure of an absolute 9.3 bar and a decline in reservoir temperature of $19^{\circ} \mathrm{C}$ from its original state[4].

Based on an exergy analysis conducted by Adiprana et al. (2015), Kamojang's Unit 1-2-3 has an exergy system loss of about $104,431 \mathrm{Kw}$ [5]. According to Illah. A. (2016) steam consumption at unit 2 plant in Indonesia Power increased from 240 ton / hour to 350 ton / hour [6]. This is due to the age of the plant which leads to a decrease in the component's performance, resulting in energy losses in the system. These energy losses leads to a decrease in system efficiency.

\footnotetext{
* Corresponding author: pambudi.agung@staff.uns.ac.id
} 
In the view of above, one method for optimizing geothermal power plants is through thermodynamic analysis with exergy. The objective of this study is using exergy analysis in evaluating and optimizing unit 2's geothermal power plant in Kamojang. The evaluation and optimization calculations will be performed using the Engineering Equation Solver (EES) code.

\section{Method}

This study uses numerical approach where data collection is done by taking data that includes data record operation and production within a certain time. The data required in this research are the steam flow rate, temperature and pressure at each state, environmental temperature, power plant power, and other data needed to support the implementation of this research. The data obtained was obtained using software Engineering Equation Solver (EES) with thermodynamic method. The design in the study is shown in Figure 1 below:

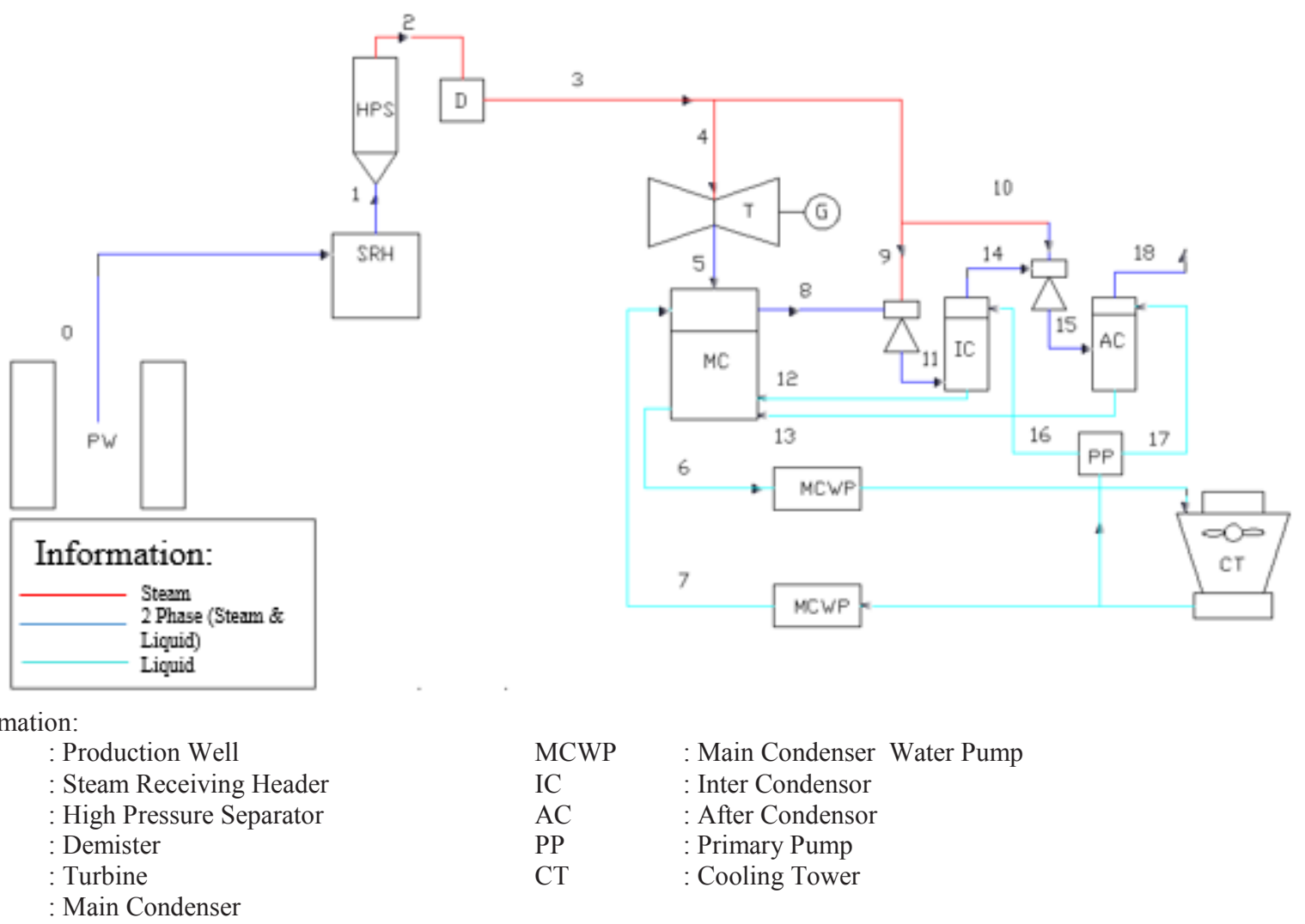

Fig. 1. Unit 2 Kamojang geothermal power plant main system diagram.

The energy analysis for the generating component can be obtained by the following Eq. (1) and (2) [7].

$$
\begin{aligned}
& \frac{d E}{d t}=Q-W \\
& Q-W=\Sigma m_{0}^{n} h_{0}^{*}-\Sigma m_{1} h_{1}^{\circ}
\end{aligned}
$$

Where, $\quad \mathbf{Q}=$ Heat entered into the system $(\mathrm{kJ} / \mathrm{s})$ $\mathrm{W}=$ Work generated by the system $(\mathrm{kJ} / \mathrm{s})$

$\mathrm{m}_{0}=$ Outgoing mass flow $(\mathrm{kg} / \mathrm{s})$

$\mathrm{m}_{1} \quad=$ Incoming mass flow $(\mathrm{kg} / \mathrm{s})$

$\mathrm{h}_{\mathrm{e}} \quad=$ Enthalpy output $(\mathrm{kJ} / \mathrm{kg})$

$\mathrm{h}_{\mathrm{i}} \quad=$ Enthalpy input $(\mathrm{kJ} / \mathrm{kg})$

For the analysis of exergy, the following Eq. (3) can be used:

$$
\mathrm{E}_{\mathrm{X}}=\mathrm{m}\left(\left(\mathrm{h}_{\mathrm{i}}-\mathrm{h}_{\mathrm{e}}\right)-\mathrm{T}_{\mathrm{e}}\left(\mathrm{s}_{\mathrm{i}}-\mathrm{s}_{\mathrm{e}}\right)\right)
$$

$$
\text { Where, } \quad \begin{aligned}
\mathrm{E}_{\mathrm{X}} & =\text { Exergy }(\mathrm{kW}) \\
\mathrm{m} & =\text { Mass flow }(\mathrm{kg} / \mathrm{s}) \\
\mathrm{h}_{\mathrm{e}} & =\text { Surrounding enthalpy }(\mathrm{kJ} / \mathrm{kg}) \\
\mathrm{h}_{\mathrm{i}} & =\text { Enthalpy input }(\mathrm{kJ} / \mathrm{kg}) \\
\mathrm{s}_{\mathrm{e}} & =\text { Surrounding enthalpy }(\mathrm{kJ} / \mathrm{kg} . \mathrm{K})
\end{aligned}
$$

And for the irreversibility (I) of each component's system can be searched by using the following Eq. (4):

$$
\mathrm{I}=\mathrm{Ex}_{\mathrm{i}}-\mathrm{Ex}_{0}
$$

Where, I = Irreversibility $(\mathrm{kW})$ 


$$
\mathrm{Ex}_{\mathrm{i}}=\text { Exergy input }(\mathrm{kW})
$$

As for knowing the performance of a power plant can use the equation of the second law of thermodynamic as follows (Eq.5) [8]:

$$
\eta_{\mathrm{II}}=\frac{\mathrm{z} \mathrm{Ex}_{0}}{\mathrm{z} \mathrm{Ex}_{\mathrm{i}}}
$$

$$
\text { Where, } \begin{aligned}
\mathrm{EEx}_{0} & =\text { Total Exergy Output }(\mathrm{kW}) \\
\mathrm{ZEx}_{\mathrm{i}} & =\text { Total Exergy Input }(\mathrm{kW})
\end{aligned}
$$

\section{Unit 2 kamojang plant}

Kamojang is one of the geothermal power plants located at Ds. Laksana, Kec. Ibun, Kab. Bandung, West Java province within $+17 \mathrm{~km}$ Northwest of Garut or $+42 \mathrm{~km}$ Southeast of Bandung, and is located at an altitude of 1640 to $1750 \mathrm{~m}$ above sea level. Geographically, it lies at a position of $107^{\circ} 37,5^{\prime}-107^{\circ} 48^{\prime}$ BT and $7^{\circ} 5,5^{\prime}$ $7^{\circ} 16,5^{\prime}$ LS. Unit 2's Kamojang geothermal power plant is managed by PT. Indonesia Power engaged in power generation as well as operation and maintenance services of power plants. Unit 2's Kamojang geothermal power plant operated early 1987 where the installed capacity was $55 \mathrm{MW}$. The plant is a dry steam plant system with a steam pressure of approximately 6.5 bar. This plant also has several components such as the steam receiving header, separator, demister, turbine, main condenser, ejector first, second ejector, inter condenser, after condenser, main cooling water pump (MCWP) and cooling tower.

\section{Results and discussion}

\subsection{Energy and exergy's system analysis}

The value of enthalpy, entropy and energy in each component according to the state is shown in table 1 below.

Table 1. Data and energy analysis.

\begin{tabular}{|l|c|c|c|c|}
\hline $\begin{array}{l}\text { Component } \\
\text { Name }\end{array}$ & State & $\begin{array}{c}\text { Enthalpy } \\
(\mathbf{k J / k g})\end{array}$ & $\begin{array}{c}\text { Enthropy } \\
(\mathbf{k J} / \mathbf{k g} . \mathbf{K})\end{array}$ & $\begin{array}{c}\text { Energy } \\
(\mathbf{k W})\end{array}$ \\
\hline From Well & 0 & 2,760 & 6.733 & 288897 \\
\hline $\begin{array}{l}\text { Steam } \\
\text { Receiving } \\
\text { Header }\end{array}$ & 1 & 2,760 & 6.733 & 89.9 \\
\hline $\begin{array}{l}\text { High } \\
\begin{array}{l}\text { Pressure } \\
\text { Separator }\end{array}\end{array}$ & 2 & 2,759 & 6.738 & 235.4 \\
\hline Demister & 3 & 2,757 & 6.754 & 521.9 \\
\hline Turbine & 4 & 2,253 & 6.788 & 58797 \\
\hline $\begin{array}{l}\text { Main } \\
\text { Condenser }\end{array}$ & 5 & 2,235 & 6.962 & 72545 \\
\hline MCWP & 6 & 549 & 1.641 & 956.1 \\
\hline $\begin{array}{l}\text { Cooling } \\
\text { Tower }\end{array}$ & 7 & 523.9 & 1.578 & 819.6 \\
\hline $1^{\text {st }}$ Ejector & 8 & 2,232 & 6.77 & 1542 \\
\hline $\begin{array}{l}\text { Motive } \\
\text { Steam 1 }\end{array}$ & 9 & 2,725 & 6.693 & 3820 \\
\hline $\begin{array}{l}\text { Motive } \\
\text { Steam 2 }\end{array}$ & 10 & 2,725 & 6.693 & 2343 \\
\hline
\end{tabular}

Table 1. Cont.

\begin{tabular}{|l|c|c|c|c|}
\hline $\begin{array}{l}\text { Component } \\
\text { Name }\end{array}$ & State & $\begin{array}{c}\text { Enthalpy } \\
(\mathbf{k J} / \mathbf{k g})\end{array}$ & $\begin{array}{c}\text { Enthropy } \\
(\mathbf{k J} / \mathbf{k g . K})\end{array}$ & $\begin{array}{c}\text { Energy } \\
(\mathbf{k W})\end{array}$ \\
\hline Int-Cond In & 11 & 2,137 & 5.302 & 4747 \\
\hline $\begin{array}{l}\text { Int-Cond } \\
\text { Out }\end{array}$ & 12 & 204.3 & 0.6882 & 219.2 \\
\hline $\begin{array}{l}\text { Aft-Cond } \\
\text { Out }\end{array}$ & 13 & 411.5 & 0.882 & 301.4 \\
\hline $2^{\text {nd } \text { Ejector }}$ & 14 & 2,172 & 6.343 & 1244 \\
\hline $\begin{array}{l}\text { After-Cond } \\
\text { In }\end{array}$ & 15 & 2,137 & 5.302 & 4468 \\
\hline $\begin{array}{l}\text { Primary Int- } \\
\text { Cond }\end{array}$ & 16 & 560.1 & 1.669 & 12.07 \\
\hline $\begin{array}{l}\text { Primary Aft- } \\
\text { Cond }\end{array}$ & 17 & 560.1 & 1.669 & 12.07 \\
\hline $\begin{array}{l}\text { Final } \\
\text { Ejector }\end{array}$ & 18 & 2,209 & 6.199 & 140.9 \\
\hline
\end{tabular}

The main component for a plant is a steam turbine that has $58,797 \mathrm{~kW}$ of energy. Though the actual work turbine is $55,000 \mathrm{~kW}$. The Steam Receiving Header (SRH) has an energy amount of $89.9 \mathrm{~kW}$ which is the energy lost due to the decrease of enthalpy that exits SRH. Meanwhile, the High Pressure Separator has a total energy of $235.4 \mathrm{~kW}$ which shows the energy lost due to the centrifugal force. This results in a pressure drop from the high pressure separator. The demister has about $521.9 \mathrm{~kW}$ of energy. In this equipment, there is energy loss because there is a vapor filtering mechanism, for cleaning before entering the turbine. Other components such as the main condenser, cooling tower, intercondenser and after-condenser have an energy value at $72,545 \mathrm{~kW}, 4,747 \mathrm{~kW}$ and $4,468 \mathrm{~kW}$, respectively. The 1 st and 2nd motive steam has an energy value of 3,820 $\mathrm{kW}$ and $2,343 \mathrm{~kW}$ respectively which is used to suck non condensable gas from the steam into the auxiliary system. Exergy analysis is performed to find out the magnitude, location and causes of irreversibility which consists of the Steam Receiving Header, High Pressure Separator, Demister, Turbine, Main Condenser, Inter Condenser, After Condenser, 1st Ejector, 2nd Ejector and Cooling Tower.

Table 2. Exergy input value, exergy output, irreversibility and exergy efficiency of each component at unit 2 in kamojang.

\begin{tabular}{|l|c|c|c|c|}
\hline $\begin{array}{c}\text { Compone } \\
\text { nt Name }\end{array}$ & $\begin{array}{c}\text { Exergy } \\
\text { input } \\
(\mathbf{k W})\end{array}$ & $\begin{array}{c}\text { Exergy } \\
\text { output } \\
\mathbf{( k W )}\end{array}$ & $\begin{array}{c}\text { Irreversib } \\
\text { ility (kW) }\end{array}$ & $\begin{array}{c}\text { Exergy } \\
\text { Efficien } \\
\mathbf{c y} \mathbf{( \% )}\end{array}$ \\
\hline $\begin{array}{l}\text { Steam } \\
\text { Receiving } \\
\text { Header }\end{array}$ & 254,432 & 254,175 & 257.5 & 99.9 \\
\hline Separator & 254,175 & 253,404 & 771 & 99.7 \\
\hline Demister & 253,404 & 237,590 & 9,309 & 96.33 \\
\hline Turbine & 245,226 & 179,545 & 64,550 & 73.56 \\
\hline Condenser & 192,109 & 61,682 & 130,420 & 32.1 \\
\hline $1^{\text {st } E j e c t o r ~}$ & 5,149 & 5,063 & 85.68 & 98.34 \\
\hline $\begin{array}{l}\text { Inter } \\
\text { Condenser }\end{array}$ & 5,128 & 4,661 & 467.2 & 90.89 \\
\hline $2^{\text {nd }}$ Ejector & 4,904 & 4,764 & 139.6 & 97.15 \\
\hline $\begin{array}{l}\text { After } \\
\text { Condenser }\end{array}$ & 4,830 & 4,128 & 701.9 & 85.47 \\
\hline $\begin{array}{l}\text { Cooling } \\
\text { Tower }\end{array}$ & 5,383 & 5,217 & 166.4 & 96.91 \\
\hline
\end{tabular}


Table 2 shows the number of the total of exergy input and output on each component. At SRH the magnitude of exergy input and output is $254,432 \mathrm{~kW}$ and 254,175 $\mathrm{kW}$ respectively. During operation this component produces an exergy loss of $257.5 \mathrm{~kW}$. This is caused by the venting process found in the vent structure. This tool serves to remove the excess steam that will enter the system. Therefore this risks in the loss of steam. In addition, the irreversibility of SRH is also caused by a steam leakage on 4 inlet pipes, 3 outlet pipes, and 2 safety valves. Steam leaks through the valve packing because the material is made of rubber. This material over time operation will experience stiffness and cracking.

In other components such as the High Pressure Separator, has an irreversibility of $771 \mathrm{~kW}$. This is caused by a centrifugal force. Particles of larger density exits the vortex and hit the separator wall and then falls down to the dust collector. Furthermore, the friction between the vapor and the separator wall resulted in a pressure drop. HPS material also uses rubber packing on its connection, resulting in leakage.

Irreversibility on other components such as the Demister also caused the same thing as HPS and SRH, i.e. rubber material. Meanwhile, in the Turbine, irreversibility caused due to a throttling process on the main stop valve and the governor valve. This process resulted in a pressure drop. During nearly 30 years of operation, the turbine blades also undergoes a plastic deformation due to the presence of solid particles still present in the vapor. This is due to a failed filtering process on the demister. The silica that falls in the steam also affects the turbine's irreversibility. Condensed silica on stage 1 and 2 turbines contributes to the greatest pressure drop. The silica deposit will cause a decrease in the turbine performance and impact on the declining ability of the plant to produce electricity.

The exergy of $192,109 \mathrm{~kW}$ contained in the main condenser comes from the remaining steam coming out of the turbine. While the exergy of $61,682 \mathrm{~kW}$ that left the condenser comes from the condensed steam and towards the cooling tower. The irreversibility of 130,427 $\mathrm{kW}$ of the main condenser comes from the process of condenser and steam heat absorbed by cold water from the cooling tower. The condenser's irreversibility is also influenced by the exhaust steam heat rejection that is the flow of steam from the turbine to the condenser. The heat transfer area of condenser is a direct contact type. The problems that often arise in the main condenser is the blockage and blocking caused by the entry of mud from the cooling tower. This results in the blockage of nozzles on the main condenser. So the water that should be sprayed in spray shape is changed in the form of water film. This resulted in higher condensate temperatures.

The inter condenser and after condenser each have an Irreversibility of $467.2 \mathrm{~kW}$ and $701.9 \mathrm{~kW}$ respectively. This Irreversibility is due to the occlusion of the nozzle tray and its components. Condensation process at the inter condenser and after condenser use the primary cooling water system which contains a lot of sulfur mud. This sulfur sludge will slowly clog the nozzles contained in the inter and after condenser. The blockage problem in the nozzle tray can be solved using a mechanical cleaning, but to perform the cleaning, the plant must be in a shutdown condition.

1 st ejector and 2nd ejector each have exergy input of $5,149 \mathrm{~kW}$ and 4,904 kW and an exergy output of 5,063 $\mathrm{kW}$ and $4,764 \mathrm{~kW}$ respectively. The Irreversibility of the 1 st ejector and 2nd ejector is of $85.68 \mathrm{~kW}$ and $139.6 \mathrm{~kW}$ respectively. Irreversibility on the 1 st ejector and 2 nd ejector is due to the blockage of the inlet and outlet hole due to a scaling and age of the components that have been operating for 30 years.

Exergy contained in the cooling tower is of $5,383 \mathrm{~kW}$ comes from the water condenser that still have a temperature of $50^{\circ} \mathrm{C}$ where the water will be cooled in the cooling tower. While the exergy of $5,217 \mathrm{~kW}$ that left the cooling tower comes from condensed steam and towards the cooling tower. The irreversibility of the cooling tower of $166.4 \mathrm{~kW}$ comes from the hot water absorbed by the cold water and the help obtained by the fan from the cooling tower.

Based on the exergy input, exergy output and exergy's irreversibility, it can be known that the excessive efficiency of each component of the system is shown in Figure 2 below:

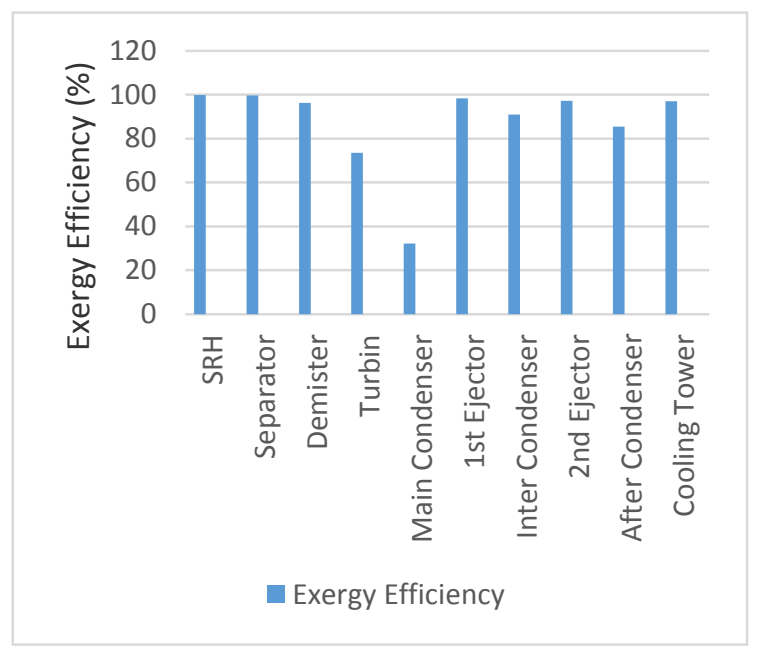

Fig. 2. Exergy efficiency bar chart of unit 2 kamojang geothermal power plant main system.

$\mathrm{SRH}$, separator and demister each have an exergy efficiency of $99.9 \%, 99.7 \%$ and $96.33 \%$ respectively. All three components have an exergy efficiency above $95 \%$ which means there is not much exergy loss on the component. The exergy efficiency of the turbine shows a value of $73.56 \%$. The exergy efficiency of the main condenser shows the figure of $32.1 \%$. The inter condenser and after condenser each have an exergy efficiency of $90.89 \%$ and $85.47 \%$ respectively. The 1 st ejector and 2nd ejector have an exergy efficiency of $98.34 \%$ and $85.47 \%$ respectively. The cooling tower component has an efficiency of $96.91 \%$. While the main condenser has the lowest exergy's efficiency compared to the components of the main condenser functioning for the condensation process of steam from the turbine heat. 


\subsubsection{Grassman Diagram and analysis performance}

Figure 3 shows available exergy that goes into the system is of $254432 \mathrm{~kW}$. Not all available exergies can be converted into an electrical energy due to an excess that is lost due to the irreversibility process. The Grassman diagram in Figure 6 shows the magnitude of the lost exergy in the SRH, separator, demister, turbine, main condenser, 1 st ejector, inter condenser, 2nd ejector, after condenser and cooling tower of $257.5 \mathrm{~kW}$ or $0.10 \%$ , $771 \mathrm{~kW}$ or $0.303 \%, 9309 \mathrm{~kW}$ or $3.65 \%, 9550 \mathrm{~kW}$ or $3.75 \%, 130420 \mathrm{~kW}$ or $51.25 \%, 85.68 \mathrm{~kW}$ or $0.033 \%$, $467.2 \mathrm{~kW}$ or $0.183 \%, 139.6 \mathrm{~kW}$ or $0.054 \%, 701.9 \mathrm{~kW}$ or $0.275 \%$ and $166.4 \mathrm{~kW}$ or $0.065 \%$ respectively and the net power generated is at $102556,72 \mathrm{~kW}$ or equal to $40.31 \%$ of the total exergy entered into the main system of Unit 2 Kamojang PLTP.

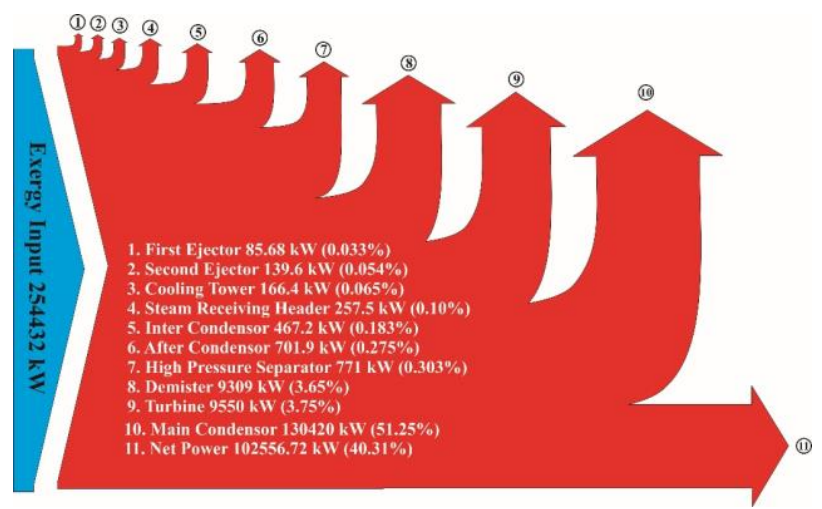

Fig. 3. Grassman diagram of unit 2 kamojang geothermal power plant main system.

Exergy performance analysis shows the net power output, first law efficiency, and second law efficiency in table 3. The net power output on the system is $102,556.72 \mathrm{~kW}$, while the first and second law efficiency is $19.03 \%$ and $40.31 \%$, respectively.

Table 3. Exergy performance analysis unit 2 kamojang geothermal power plant system.

\begin{tabular}{|c|c|}
\hline Parameter & Performance \\
\hline Net power output (kW) & $102,556.72$ \\
\hline first law efficiency (\%) & 19.03 \\
\hline second law efficiency (\%) & 40.31 \\
\hline
\end{tabular}

If we compare to other plant, for example in Dieng plant, the Kamojang has higher efficiency. In Dieng it is reported that their first and second efficiency are $11.62 \%$ and $36.7 \%$, respectively [9]. The kamojang power plant has higher efficiency since it is a dry steam technology while in Dieng is flash technology. Dry steam technology, the steam from the production well is directed to the tubin and activates the generator to produce electricity [10]. Dry steam power plant is not widely used since the type of vapor-dominated reservoir is rare. In the world there are known 4 geothermal resources with vapor-dominated reservoirs among them are Kamojang, Darajat, The Geysers, Lardarello [11].

\section{Conclusions}

The result of energy and exergy analysis on Unit 2's Kamojang geothermal power plant gives information about the amount of energy produced by the turbine at $58,797 \mathrm{~kW}$ and the location and magnitude of the irreversibility occurred in the main condenser is at $130,420 \mathrm{~kW}$. The plant shows that the first law efficiency and second law efficiency of $19.03 \%$ and $40.31 \%$ respectively.

\section{References}

1. Ministry of Energy and Mineral Resources Republic of Indonesia, Jurnal Energi Media Komunikasi Kementrian Energi dan Sumber Daya Mineral (www.esdm.go.id/, 2016)

2. Ministry of Energy and Mineral Resources Republic of Indonesia, RENSTRA KESDM 2015 - 2019 (www.esdm.go.id/, 2015)

3. Ministry of Energy and Mineral Resources Republic of Indonesia, Handbook of Energy \& Economic Statistics of Indonesia 2016 (ISNN 2528-3464, 2016)

4. Suryadarma, T. Dwioriyanto, A.A. Zuhro, A. Yani, "Sustainable Development of The Kamojang Geothermal Field," Geothermics 39, 391-399 (2010)

5. R. Adiprana, D.S. Purnomo, I.E. Lubis, "Kamojang Geothermal Power Plant Unit 1-2-3 Evaluation and Optimization Based on Exergy Analysis," Proceedings World Geothermal Congress 2015, Melbourne, Australia (2015)

6. Illah, I. Atho. Analisis Eksergi Sistem Pembangkit Listrik Tenaga Panas Bumi Siklus Uap Hasil Pemisahan (Separated Steam Cycle) di Pt. Indonesia Power Upjp Kamojang. (Thesis, 2016, not published)

7. B. Rudiyanto, et al. "Preliminary Analysis of DrySteam Geothermal Power Plant by Employing Exergy Assessment: Case Study in Kamojang Geothermal Power Plant, Indonesia," Case Studies in Thermal Engineering 17, 391-399 (2017)

8. R. DiPippo, Geothermal power plants, Principles, Applications, Case Studies and Environmental Impact (Third Edition) (Elsevier Ltd, Oxford, 2012)

9. N.A. Pambudi, et al. "Preliminary analysis of single flash combination with binary system using thermodynamic assessment: a case study of Dieng geothermal power plant," International Journal of Sustainable Engineering (Taylor \& Francic, London, 2014)

10. R. DiPippo, Geothermal power plants, Principles, Applications, Case Studies and Environmental Impact (Second Edition) (Elsevier Ltd, Oxford, 2008)

11. M. Grant, P. Bixley, Geothermal Resevoir Engineering (Second Edition) (Academic Press, Cambridge USA, 2011) 